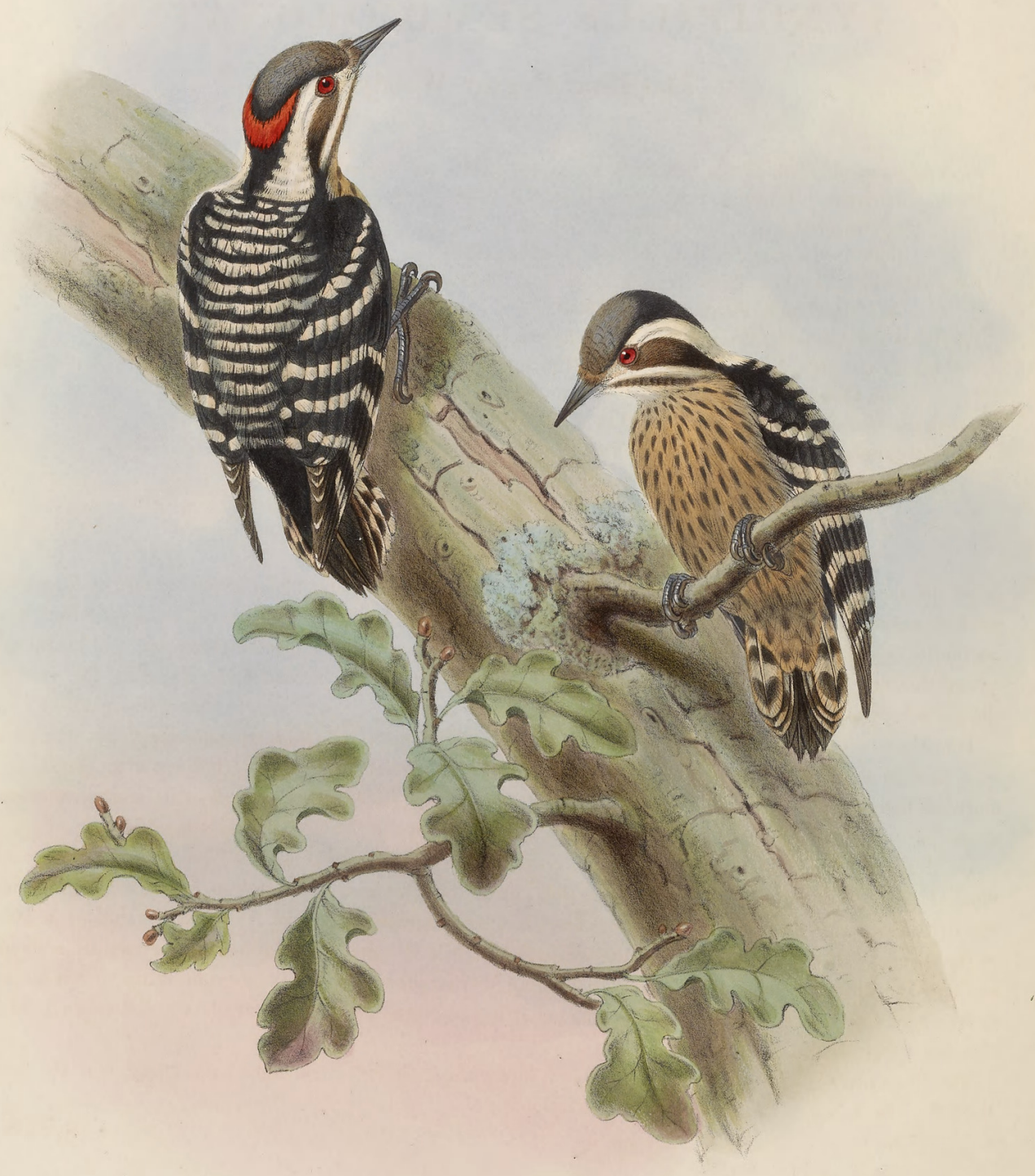

IYNGIPICUS SEMICORONATUS. 


\section{YNGIPICUS SEMICORONATUS.}

\section{Darjiling Pygmy Woodpecker.}

Picus pygmaus, old bird, Blyth, J. A. S. B. xiv. p. 197 (1845, nec Vigors).

Picus semicoronatus, Malherbe, Bull. Soc. d’Hist. Nat. Metz, 1848, p. 21.-Id. Monogr. Picid. i. p. 148, pl. xxxiv. fig. 8 (1861).-Sundev. Consp. Av. Picin. p. 27, no. 76 (1866).-Gray, List Picidæ Brit. Mus. p. 40 (1868).-Id. Hand-1. B. ii. p. 184, no. 8584 (1870).

Picus mubricatus, Blyth, J. A. S. Beng. xviii. p. 804 (1849).-Id. Cat. B. Mus. As. Soc. p. 63, no. 299 (1849).Reichb. Handb. Picinæ, p. 373 (1854).

Yungipicus semicoronatus, Bp. Consp. Volucr. Zygod. p. 8 (1854).

Yungipicus rubricatus, Jerd. B. Ind. i. p. 276 (1862).-Bulger, Ibis, 1869, p. 156.-Jerd. Ibis, 1872, p. 8.-Hume and Oates, Str. F. 1875 , p. $60 .-$ Hume, Str. F. 1879 , p. 87.

Baopipo semicoronatus, Cab. et Heine, Mus. Hein. Th. iv. p. 54 (1863).

Iyngipicus semicoronatus, Hargitt, Ibis, 1882, p. 25.

IT will be seen by the above synonymy that Blyth at first supposed this species to be the old bird of 1 . pygmaus but four years later, during a revision of the genus, he concluded that the perfect red coronet, which he had previously considered to be a sign of old age, really indicated a distinct specific character, and he therefore named the bird $P$. rubracalus. It so happened, however, that Malherbe had fully described the species in the previous year as $P$. semicoronatus, which name therefore has precedence over that given by Blyth.

There are two species which stand alone in the possession of a red band on the occiput, viz. the present bird and another called $P$. meniscus by Malherbe. The latter is a species unknown to ornithologists since Malherbe's time; but it differs in having the central tail-feathers spotted with white, whereas in I. semicoronatus the four central tail-feathers, as well as the upper tail-coverts, are entirely black.

Dr. Jerdon states that the present species is not very rare in Nepal and Sikhim. As Mr. Hargitt has pointed out, however, no specimens from the former country are contained in Mr. Hodgson's series in the British Museum; so that Jerdon must have had some further authority for giving Nepal as a habitat of the species. It doubtless occurs to the westward, as Mr. Hargitt has identified a specimen from Jeypoor in Capt. Wardlaw Ramsay's collection as belonging to the present species. Jerdon states that it is found in Northern Cachar, and Mr. Chennell collected it in the North Khasia hills, while Colonel Godwin-Austen obtained specimens in the Naga hills.

The Plate gives a representation of a pair of birds, the male being the right-hand figure, and the female the left. Both are of the natural size. 


\section{$2 \mathrm{BHL}$ Biodiversity Heritage Library}

Gould, John. 1883. "Darjiling Pygmy Woodpecker, Iyngipicus semicoronatus [PI. 26]." The Birds of Asia 6(XXXIV), -. https://doi.org/10.5962/p.323380.

View This Item Online: https://www.biodiversitylibrary.org/item/122488

DOI: https://doi.org/10.5962/p.323380

Permalink: https://www.biodiversitylibrary.org/partpdf/323380

\section{Holding Institution}

Smithsonian Libraries

\section{Sponsored by}

Smithsonian Institution Libraries

\section{Copyright \& Reuse}

Copyright Status: Not in copyright

This document was created from content at the Biodiversity Heritage Library, the world's largest open access digital library for biodiversity literature and archives. Visit BHL at https://www.biodiversitylibrary.org. 